\title{
Improved nitrogen metabolism in rats fed on lipid-rich liquid diets
}

\author{
BY ERNESTO ESTORNELL ${ }^{1}$, TERESA BARBER ${ }^{1}$ AND JOSÉ CABO \\ Departament de Bioquímica i Biologia Molecular, Universitat de València, ${ }^{1}$ Facultat de Farmàcia \\ and ${ }^{2}$ Facultat de Medicina i Odontologia, Avgda Blasco Ibáñez 17, 46010-València, Spain
}

(Received 23 October 1992 - Revised 5 May 1993 - Accepted 28 May 1993)

\begin{abstract}
$\mathbf{N}$ metabolism was studied in young rats fed on lipid-rich, isonitrogenous, purified liquid diets, a convenient and easy technique for inducing voluntary overfeeding of energy and lipids under controlled nutritional conditions. Overfed rats showed a marked $\mathrm{N}$ retention at the expense of a reduced production of urea. The capacities of isolated hepatocytes to synthesize urea and glucose from added precursors were greatly diminished. The activities of the urea cycle enzymes and several enzymes involved in the availability of $\mathrm{NH}_{3}$ for this pathway were concomitantly reduced in overfed animals. Therefore, our results showed an improved $\mathrm{N}$ metabolism in overfed rats promoted by the overfeeding of lipids that could be due to an enhanced biosynthetic utilization and a reduced catabolism of amino acids. In addition, the versatile and accurate technique for inducing overfeeding in young rats used in the present study could have many advantages for nutritional studies.
\end{abstract}

Overfeeding: Liquid diet: Nitrogen metabolism: Urea cycle

The sensitivity of $\mathrm{N}$ balance to changes in energy intake has been demonstrated in numerous studies. It is well known that when diet provides adequate amounts of protein the addition of energy-yielding nutrients (either carbohydrate or fat) results in a linear improvement in $\mathrm{N}$ balance in humans and animals (Munro, 1951, 1964, 1978; Inoue et al. 1973; Garza et al. 1976; Reeds et al. 1981). However, the underlying biochemical mechanism whereby energy intake above requirements affects $\mathrm{N}$ metabolism in long-term studies remains obscure.

In a previous paper (Barber et al. 1985) we reported an increased $\mathrm{N}$ retention in cafeteriafed rats, a model of voluntary hyperphagia of fat-rich food in which animals were offered a variety of palatable supermarket foods (Rothwell \& Stock, 1979). This finding was in agreement with the protein-sparing effect of fat. Our experimental results with this model suggested that the marked $\mathrm{N}$ retention was due to a decrease in amino acid catabolism and in urea production by the liver (Barber et al. 1985, 1987). The cafeteria-feeding regimen has contributed substantially to the understanding of energy balance regulation (Rothwell \& Stock, 1981); however, it has been criticized because it is difficult to exert adequate control over the diet composition (Moore, 1987).

Studies on the metabolic adaptations induced by dietary manipulations require strict control of the nutritional composition of the diets to obtain clear results. Most studies performed in overfed animals have been carried out using diets which do not provide the established nutritional requirements (National Research Council, 1978). Frequently protein intake is below requirement levels in high-fat and high-sucrose diets. In cafeteria diets most of the components of the food are unknown. In this sense it is important to ensure that, apart from the subject of the study, the intake of each component of the diet, including micronutrients is maintained at a constant level. 
The present work was designed to study the protein-sparing effect of fat on both $\mathrm{N}$ balance and amino acid catabolism by using a novel feeding technique developed as an easy model of voluntary intake of lipid-rich, isonitrogenous liquid diets. The liquid diets were prepared with products of precisely known composition to allow accurate control of each individual component. Advantages of this overfeeding-induction technique and possible applications for other nutritional studies are discussed.

After a brief physiological characterization of our overfeeding model, we studied the total $\mathrm{N}$ and $\mathrm{N}$ compound balances. The increased $\mathrm{N}$ retention at the expense of reduced urinary excretion of urea led to our interest in exploring the processes involved in hepatic amino acid catabolism. Thus, we evaluated the capacity of isolated hepatocytes to synthesize urea and glucose. Indeed, we found a diminished capacity to produce urea and glucose in the hepatocytes isolated from overfed rats. In addition we studied the activities of the enzymes of the urea cycle and those involved in general amino acid metabolism and glucose production by the liver. The enhanced $\mathbf{N}$ retention, diminished urea production, inhibited glucose formation and reduced activities of key enzymes, mainly those concerning urea synthesis, promoted in rats by overfeeding on high-energy, lipid-rich, isonitrogenous liquid diets represented improved $\mathrm{N}$ metabolism, as discussed.

\section{MATERIALS AND METHODS}

\section{Experimental design and diets}

Male Wistar rats (Panlab S.L., Barcelona, Spain) were housed in groups of four or five animals per cage after weaning. They were fed $a d l i b$ on a commercial solid non-purified diet (Panlab S.L.) and tap water under controlled conditions of light ( $12 \mathrm{~h}$ light-12 h dark, lights on at 08.00 hours) and temperature $\left(22 \pm 1^{\circ}\right)$. When rats reached weights of $160-180 \mathrm{~g}$ they were placed in individual cages and randomly divided in two groups: control and overfed. The control group was fed on the purified liquid diet $\mathrm{C}$ (control diet) for $21 \mathrm{~d}$. The overfed group was fed on two high-energy, lipid-rich, isonitrogenous liquid diets: $\mathrm{H}^{1}$ and $\mathrm{H}^{2}$.

Diet $\mathrm{C}$ was formulated to meet the National Research Council (1978) recommendations and those of the American Institute of Nutrition (1977) and adapted to liquid form on the basis given by Lieber \& De Carli $(1982,1986)$. The composition $(\mathrm{g} / \mathrm{l})$ of diet $\mathrm{C}$ was : casein (vitamin-free) $52 \cdot 0$, DL-methionine $0 \cdot 8$, dextrin $162 \cdot 7$, maize oil $13 \cdot 0$, AIN-76A vitamin mix $2 \cdot 6$, AIN-76 mineral mix $9 \cdot 1$, choline chloride $0 \cdot 3$, cellulose powder $10 \cdot 0$, xanthan gum $2 \cdot 0$ and distilled deionized water to 11 . Sucrose, originally used as the main carbohydrate source, was omitted in order to avoid the induction of an excessive intake of energy (Ramirez, 1987) and replaced by an isoenergetic quantity of dextrin (Reeves, 1989). The energy density of the diet was $4 \cdot 18 \mathrm{MJ} / 1(1000 \mathrm{kcal} / \mathrm{l})$ and its distribution (\% of energy) was: protein 22 , carbohydrate 66 , lipid 12 . Energy values of diet ingredients $(\mathrm{kJ} / \mathrm{g})$ were based on published data: casein 17.86 , maize oil 37.45 , dextrin 16.57 . Daily, each animal was offered fresh diet in an open-bottomed graduated cylinder at a pre-fixed volume that allowed the same intake of energy and protein as that of animals fed on pelleted standard diet (i.e. $2 \cdot 7-3 \cdot 0$ g protein $/ 24 \mathrm{~h}$ and $200-230 \mathrm{~kJ} / 24 \mathrm{~h}$ ).

The $\mathrm{H}^{1}$ diet was designed for rapid overfeeding of the animals by increasing the lipid content to obtain a $40 \%$ increment in energy with respect to diet $\mathrm{C}: 57.7 \mathrm{~g}$ maize oil $/ 1$ and $5.86 \mathrm{MJ} / 1(1400 \mathrm{kcal} / \mathrm{l})$. This diet was given to the rats for $10 \mathrm{~d}$. Afterwards it was replaced by diet $\mathrm{H}^{2}$ which was designed to have a $25 \%$ increment in energy density: $41.0 \mathrm{~g}$ maize oil/1 and $5.23 \mathrm{MJ} / 1(1250 \mathrm{kcal} / \mathrm{l})$. Rats were offered this diet for a further $11 \mathrm{~d}$. Concentrations of all other components in diets $\mathrm{H}^{1}$ and $\mathrm{H}^{2}$ were maintained at the same level with respect to diet $\mathrm{C}$. This was done in order to ensure the same intake and 
nutritional quality of all nutrients (except lipids) with respect to diet $\mathrm{C}$. Each day each animal received fresh diet at the same volume as the control group: $\operatorname{diet} \mathbf{H}^{1}$ between days 1 and 10 and diet $\mathrm{H}^{2}$ between days 11 and 21 . The replacement of diet $\mathrm{H}^{1}$ by diet $\mathrm{H}^{2}$ at day 11 was done in order to avoid the decrease in voluntary intake of the first diet shown by the animals beyond this limit.

Vitamin (AIN-76A) mix, mineral (AIN-76) mix and casein (micropulverized, vitaminfree) were purchased from ICN Biomedicals, High Wycombe, Bucks. Pure maize oil without additions and other compounds used for the formulation of diets were obtained from Sigma Chemical Co., St Louis, MO, USA.

\section{Samples}

During the last $48 \mathrm{~h}$ of the dietary treatment the animals were placed in individual metabolic cages for collection of urine and faeces. The urine samples were collected every $24 \mathrm{~h}$ into $25 \mathrm{ml}$ test-tubes containing $0.5 \mathrm{ml} 6 \mathrm{M}-\mathrm{HCl}$. Faeces were collected every $24 \mathrm{~h}$ and homogenized with water in a motor-driven Teflon-glass homogenizer at adequate dilutions for $\mathrm{N}$ content assay. Blood was collected in heparinized tubes from the retroorbital plexus under light diethyl ether anaesthesia.

Rats were killed by decapitation after the $21 \mathrm{~d}$ dietary treatment, between 10.00 and 12.00 hours to minimize diurnal variations. Livers were rapidly excised, weighed, frozen between two aluminum blocks pre-cooled in liquid $\mathrm{N}_{2}$ and conserved at $-30^{\circ}$ until analyses were done. Selected fat pads were excised and weighed. For isolation of hepatocytes, rats were starved for $24 \mathrm{~h}$ and anaesthetized with Pentothal $(60 \mathrm{mg} / \mathrm{kg}$ body weight in $9 \mathrm{~g} \mathrm{NaCl} / \mathrm{l}$ ) before the procedure.

\section{Isolation of hepatocytes}

The preparation of isolated hepatocytes approximated to the method of Berry \& Friend (1969). Cells (15-20 mg wet weight/ml) were incubated for $40 \mathrm{~min}$ in Krebs-Henseleit bicarbonate buffer containing $3 \mathrm{~mm}-\mathrm{Ca}^{2+}$ and appropriate additives (at $10 \mathrm{~mm}$ of each one) for urea synthesis (none, alanine, ammonia plus ornithine, ammonia plus ornithine plus lactate) and for glucose synthesis (fructose, glycerol, pyruvate, lactate and alanine). Urea and glucose synthesis were constant over the incubation period. Viability was assessed routinely by the trypan-blue exclusion. In all cases more than $85 \%$ of the cells excluded the colourant.

\section{Analytical determinations}

The following metabolites were measured: urea (Nuzum \& Snodgrass, 1976), creatinine (Naranayan \& Appleton, 1980) and glucose (Bergmeyer \& Bernt, 1974a). Analysis of N content was by Kjeldahl digestion and Nessler's reaction as modified by Minari \& Zilversmit (1963). Total lipids were assayed as described by Frings et al. (1972). Triacylglycerols (Nägele et al. 1984), total cholesterol (Siedel et al. 1983) and cholesterol bound to high-density lipoproteins (HDL; Warnick et al. 1979) were measured by routine enzymic methods.

\section{Enzyme assays}

The following glucose-metabolism-related enzymes were assayed: glucose-6-phosphatase (EC 3.1.3.9; Baginski et al. 1974), fructose-1,6-biphosphatase (EC 3.1.3.11; Opie \& Newsholme, 1967), phosphoenolpyruvate carboxykinase (EC 4.1.1.32; Shimazu \& Ogasawara, 1975), pyruvate carboxylase (EC 6.4.1 .1; McClure et al. 1971), and pyruvate 
kinase (EC 2.7.1.40; Gutmann \& Bernt, 1974). Urea-cycle enzyme activities were measured in liver homogenates as follows: carbamoylphosphate synthetase I $(E C 6.3 .4 .16)$ and ornithine carbamoyltransferase $(E C 2.1 .3 .3)$ as the rate of citrulline production, argininosuccinate synthetase ( $E C$ 6.3.4.5), argininosuccinate lyase $(E C$ 4.3.2.1) and arginase (EC 3.5.3.1) as the rate of urea production (Schimke, 1962; Barber et al. 1985, 1987). Hepatic aspartate aminotransferase (EC 2.6.1.1; Bergmeyer \& Bernt, 1974b), alanine aminotransferase (EC 2.6.1.2; Bergmeyer \& Bernt, 1974c) and glutamate dehydrogenase (EC 1.4.1.3; Grisolía et al. 1964) were measured in liver by kinetic NADH-coupled methods. Carbamoylphosphate synthetase I was measured by competitive indirect enzyme-linked immunosorbent assay (ELISA) with carbamoylphosphate synthetase I polyclonal antibodies prepared by standard methods (a kind gift from Dr J. Timoneda). The assay conditions approximated to those established previously by Cerdá et al. (1988).

\section{Presentation of results}

Results in the table are presented as the mean value for each set of animals. Variability was estimated by the standard error of the mean. Responses in the control and overfed groups were subjected to one-way analyses of variance and significance tests were carried out at the $5 \%$ level. Differences between groups are expressed as the percentage change in the overfed group relative to the control group.

\section{RESULTS AND DISCUSSION \\ Model of overfeeding on liquid diets}

The first objective of the present work was the development of a new model of controlled overfeeding in young rats suitable for studies on metabolic responses to dietary manipulations. We selected the liquid-diet form, an easy and convenient technique in which the modification and the adjustment of the level of each nutrient becomes simple and accurate. An important premise in our experimental design was the isolation of only one nutritional factor for manipulation; the amount of lipid, avoiding alterations in the intake of other nutrients, particularly protein. In this sense our diets allowed us to feed the animals at the same level of protein, carbohydrates, vitamins and minerals, all except the amount of lipid and consequently of energy. Moreover we did not introduce modifications in the nutritional quality of diets, i.e. composition of amino acids or fatty acids. In addition it was necessary that diets were voluntarily accepted by the animals, in order to avoid stressful actions such as forced tube feeding, and that they were given for a convenient period to study the adaptive changes in $\mathrm{N}$ metabolism.

Table 1 shows the nutritional treatment of both groups of animals, control and overfed. The overfed group received $32 \%$ more energy than the control group in the whole dietarytreatment period. During the first period (days 1-10) the overfed rats ingested an energy excess of $37 \%$ with the aid of the energy-rich diet $\mathrm{H}^{1}$. In the second period, in which diet $\mathrm{H}^{2}$ was offered, the energy excess was $26 \%$, adequate for sustaining the overfeeding until day 21. Lipid intakes of the overfed group through the two periods exhibited more marked differences, these being 4.3 and 3.2 times the intake of the control group in the first and second periods respectively. The overall change was 3.7-fold. Importantly, protein, carbohydrate and micronutrient intakes were the same, as revealed by the unchanged dietvolume intake.

As we have shown in Table 1, the final nutritional treatment of the animals was in accordance with all our experimental premises. The liquid-diet technique provided an easy method for measuring the exact intake of each nutrient and facilitated the dietary 
Table 1. Diet, energy and major-nutrient intakes of control and overfed rats $\dagger$

(Values are means with their standard errors for twelve animals)

\begin{tabular}{|c|c|c|c|c|c|c|}
\hline \multirow[t]{2}{*}{ Treatment group... } & \multicolumn{2}{|c|}{ Control $\ddagger$} & \multicolumn{2}{|c|}{ Overfed } & \multirow{2}{*}{$\begin{array}{c}\text { Percentage } \\
\text { change }\end{array}$} & \multirow{2}{*}{$\begin{array}{l}\text { Statistical } \\
\text { significance } \\
\text { of change }\end{array}$} \\
\hline & Mean & SEM & Mean & SEM & & \\
\hline \multicolumn{7}{|l|}{ Diet intake } \\
\hline Daily (ml/24 h) & $53 \cdot 1$ & 1.0 & $52 \cdot 8$ & 1.4 & -1 & NS \\
\hline Total (ml) & 1106 & 2 & 1105 & 21 & -0 & NS \\
\hline \multicolumn{7}{|l|}{ Energy intake } \\
\hline \multicolumn{7}{|l|}{ Daily $(\mathrm{kJ} / 24 \mathrm{~h})$} \\
\hline First period & 218 & 4 & 299 & 8 & +37 & $*$ \\
\hline Second period & 226 & 2 & 285 & 6 & +26 & * \\
\hline Total (MJ) & $4 \cdot 63$ & 0.06 & 6.09 & $0 \cdot 11$ & +32 & * \\
\hline \multicolumn{7}{|l|}{ Protein intake } \\
\hline Daily $(\mathrm{g} / 24 \mathrm{~h})$ & $2 \cdot 80$ & 0.05 & $2 \cdot 79$ & 0.07 & -1 & NS \\
\hline Total (g) & $58 \cdot 4$ & 0.8 & $57 \cdot 9$ & 0.8 & -1 & NS \\
\hline \multicolumn{7}{|l|}{ Lipid intake } \\
\hline \multicolumn{7}{|l|}{ Daily $(\mathrm{g} / 24 \mathrm{~h})$} \\
\hline First period & 0.678 & $0 \cdot 014$ & $2 \cdot 93$ & 0.08 & +332 & * \\
\hline Second period & 0.703 & 0.008 & $2 \cdot 24$ & 0.05 & +219 & $*$ \\
\hline Total $(\mathrm{g})$ & $14-59$ & $0 \cdot 15$ & 53.6 & $1 \cdot 0$ & +267 & * \\
\hline \multicolumn{7}{|l|}{ Carbohydrate intake } \\
\hline Daily (g/24 h) & $8 \cdot 83$ & $0 \cdot 14$ & $8 \cdot 8$ & $0 \cdot 2$ & -1 & NS \\
\hline Total $(\mathrm{g})$ & 184 & 2 & 184 & 3 & -0 & NS \\
\hline
\end{tabular}

NS, not significant.

* $P<0.05$.

$\dagger$ For details of diets and procedures, see pp. 362-363.

+ The control group was fed on liquid diet C (4-18 MJ/1) for $21 \mathrm{~d}$. The overfed group was fed on liquid diet $\mathrm{H}^{1}(5.86 \mathrm{MJ} / 1)$ for $10 \mathrm{~d}$ and liquid $\operatorname{diet} \mathrm{H}^{2}(5.23 \mathrm{MJ} / 1)$ for the remaining $11 \mathrm{~d}$. Nutrient intakes that were different between the two consecutive periods (days 1-10 and days 11-21, as energy and lipid intakes) are given separately.

manipulations component by component (day by day if necessary) under strict nutritional control. Indeed, the proposed model of overfeeding is just one possibility for this versatile technique.

\section{Characterization of the overfed animals}

Overfed rats showed an increase in total body weight $(20 \%$ change relative to the final weight of the control group) accompanied by a marked development of the adipose tissue mass, as shown in Table 2 . Weights of three important adipose tissue pads measured in this study were increased in the overfed animals. The retroperitoneal zone showed the greatest deposition of fat in absolute terms $(+1 \cdot 35 \mathrm{~g})$. However, the relative change was greater in the pericardial zone (approximately twofold). Values in Table 2 also show the contribution of each pad to body weight, pointing out an impaired adipose tissue:body weight development. The liver also showed a large increment in its lipid content, both absolute mass and tissue concentration. It is notable that the increment in liver weight in the overfed group (19\%) had important consequences in the subsequent study of hepatic metabolism, although it was in proportion to the increased size of these animals.

It is noteworthy that fat gain was significant in overfed animals as a consequence of the energy excess ingested in spite of the use of maize oil and dextrin in the formulation of the diets. These components have been reported to result in low fat gains compared with sucrose and other fats commonly used (Baltzell \& Berdanier, 1985; McCargar et al. 1989 a). 
Table 2. Physiological variables and plasma lipids of control and overfed rats $\dagger$

(Values are means with their standard errors for twelve animals for body and adipose-tissue weights and for six animals for other variables)

\begin{tabular}{|c|c|c|c|c|c|c|}
\hline \multirow[t]{2}{*}{ Treatment group ... } & \multicolumn{2}{|c|}{ Control } & \multicolumn{2}{|c|}{ Overfed } & \multirow{2}{*}{$\begin{array}{l}\text { Percentage } \\
\text { change }\end{array}$} & \multirow{2}{*}{$\begin{array}{l}\text { Statistical } \\
\text { significance } \\
\text { of change }\end{array}$} \\
\hline & Mean & SEM & Mean & SEM & & \\
\hline \multicolumn{7}{|l|}{ Body wt } \\
\hline Initial (g) & $170 \cdot 9$ & $1 \cdot 2$ & $171 \cdot 4$ & 1.9 & +0 & NS \\
\hline Final $(\mathrm{g})$ & 228 & 3 & 275 & 6 & +20 & $*$ \\
\hline \multicolumn{7}{|l|}{ Adipose tissue mass } \\
\hline \multicolumn{7}{|l|}{ Epididymal } \\
\hline Total $(\mathrm{g})$ & $2 \cdot 12$ & 0.09 & $2 \cdot 88$ & $0 \cdot 11$ & +36 & * \\
\hline Relative (\%) & 0.93 & 0.04 & $1 \cdot 05$ & 0.04 & +13 & * \\
\hline \multicolumn{7}{|l|}{ Retroperitoneal } \\
\hline Total $(\mathrm{g})$ & $1 \cdot 65$ & $0 \cdot 17$ & $3 \cdot 0$ & 0.3 & +84 & * \\
\hline Relative (\%) & 0.72 & 0.08 & $1 \cdot 11$ & $0 \cdot 10$ & +54 & * \\
\hline \multicolumn{7}{|l|}{ Pericardial } \\
\hline Total $(\mathrm{g})$ & 0.283 & 0.010 & 0.59 & 0.03 & +107 & * \\
\hline Relative (\%) & 0.124 & $0 \cdot 003$ & 0.213 & 0.008 & +72 & * \\
\hline \multicolumn{7}{|l|}{ Liver } \\
\hline Weight $(\mathrm{g})$ & $9 \cdot 0$ & $0 \cdot 3$ & $10 \cdot 7$ & 0.5 & +18 & * \\
\hline \multicolumn{7}{|l|}{ Total lipids } \\
\hline Concentration (mg/g) & $60 \cdot 5$ & 1.8 & 102 & 4 & +69 & * \\
\hline Total (mg) & 495 & 25 & 976 & 54 & +97 & * \\
\hline \multicolumn{7}{|l|}{ Plasma } \\
\hline Total lipids (mg/l) & 4330 & 190 & 4480 & 80 & +3 & NS \\
\hline Triacylglycerols (mg/l) & 2020 & 100 & 2050 & 70 & +1 & NS \\
\hline Total cholesterol (mg/l) & 2050 & 60 & 2170 & 30 & +6 & NS \\
\hline HDL-cholesterol (mg/l) & 490 & 20 & 427 & 17 & -12 & NS \\
\hline
\end{tabular}

NS, not significant; HDL, high-density lipoprotein.

$* P<0.05$.

$\dagger$ For details of diets and procedures, see pp. 362-363.

Table 2 also shows the plasma concentrations of total lipids, triacylglycerols, total cholesterol and HDL-cholesterol. No significant changes were observed in these variables in spite of the large difference in lipid intake between two groups of animals.

\section{Nitrogen compounds}

According to our experimental design, $\mathrm{N}$ intake was the same in both groups of animals (Table 3). However, $\mathrm{N}$ excretion was substantially different: while faecal excretion remained unchanged, the urinary excretion of total $\mathrm{N}$ was greatly diminished in overfed animals. Therefore, the daily $\mathrm{N}$ retention was greatly enhanced in these animals, at least at the end of the nutritional treatment when the analyses were conducted. This fact was in agreement with the known protein-sparing effect of fat (Munro, 1951, 1978; Reeds et al. 1981; Barber et al. 1985; McCargar et al. $1989 a, b$ ). The difference in urinary $\mathrm{N}$ excretion correlated with the decrease in urinary urea excretion shown by overfed rats at the same time. Furthermore, the urinary total $\mathrm{N}$ : urea- $\mathrm{N}$ value was the same in both groups. The concentration of creatinine in plasma and the daily creatinine excretion were similar in control and overfed groups. Thus, the renal clearance of this metabolite was not significantly affected by the quantitative differences in the diets.

The quantity of $\mathrm{N}$ retained $(72 \mathrm{mg} / 24 \mathrm{~h}$ ) correlated well with the increment in body 
Table 3. Nitrogen balance and major nitrogen-containing compounds in serum and urine of control and overfed rats $\dagger$

(Values are means with their standard errors for six animals)

\begin{tabular}{|c|c|c|c|c|c|c|}
\hline \multirow[t]{2}{*}{ Treatment group... } & \multicolumn{2}{|c|}{ Control } & \multicolumn{2}{|c|}{ Overfed } & \multirow{2}{*}{$\begin{array}{l}\text { Percentage } \\
\text { change }\end{array}$} & \multirow{2}{*}{$\begin{array}{l}\text { Statistical } \\
\text { significance } \\
\text { of change }\end{array}$} \\
\hline & Mean & SEM & Mean & SEM & & \\
\hline \multicolumn{7}{|l|}{$\mathrm{N}$} \\
\hline Intake (mg N/24 h) & 450 & 4 & 441 & 6 & -2 & NS \\
\hline \multicolumn{7}{|l|}{ Excretion } \\
\hline $\begin{array}{l}\text { Urine }(m g ~ N / 24 h) \\
\text { Freces }(m g / 24 h \mathrm{~h}\end{array}$ & 233 & 10 & 150 & 9 & -37 & $\stackrel{*}{*}$ \\
\hline Faeces (mg N/24 h) & 14 & 3 & 15 & 3 & +5 & NS \\
\hline Balance $(\mathrm{mg} \mathrm{N} / 24 \mathrm{~h})$ & 203 & 3 & 275 & 7 & +35 & $*$ \\
\hline \multicolumn{7}{|l|}{ Urea } \\
\hline Urine $(\mathrm{mmol} / 24 \mathrm{~h})$ & $7 \cdot 0$ & $0 \cdot 4$ & $4 \cdot 4$ & $0 \cdot 2$ & -37 & * \\
\hline $\begin{array}{l}\text { Urinary urea-N: } \\
\text { total } N(\%)\end{array}$ & $83 \cdot 5$ & 1.7 & 81 & 2 & -3 & NS \\
\hline Plasma $(\mu \mathrm{mol} / \mathrm{ml})$ & $7 \cdot 2$ & $0 \cdot 3$ & 6.8 & $0 \cdot 3$ & -5 & NS \\
\hline \multicolumn{7}{|l|}{ Creatinine } \\
\hline Urine $(\mu \mathrm{mol} / 24 \mathrm{~h})$ & 57 & 5 & 51 & 7 & -11 & NS \\
\hline Plasma (nmol/ml) & 27.9 & $1 \cdot 3$ & $27 \cdot 0$ & 1.5 & -3 & NS \\
\hline Clearance $(\mathrm{ml} / \mathrm{min})$ & 1.41 & 0.08 & $1 \cdot 29$ & $0 \cdot 10$ & -8 & NS \\
\hline
\end{tabular}

NS, not significant.

$* P<0.05$.

$\dagger$ For details of diets and procedures, see pp. 362-363.

weight shown by the overfed rats, assuming that this $\mathrm{N}$ was used to form protein mass $(16 \% \mathrm{~N})$ and the protein content of the whole body did not change $(18 \%$ of protein in the whole rat). Obviously, $\mathrm{N}$ retention increased progressively throughout the dietary treatment. Therefore, the calculated value of $53 \mathrm{~g}$ was greater than the real one of $47 \mathrm{~g}$. The main factor responsible for the $\mathrm{N}$ imbalance was the reduced urinary output of $\mathrm{N}$, parallel to a diminished urea excretion (Table 3). The unaltered creatinine balance and the maintenance of the same plasma urea level discounted possible alterations in renal function that could block urea excretion. In this sense, the reduced urinary urea excretion could be due to reduced urea formation.

\section{Urea and glucose synthesis by isolated hepatocytes}

In order to obtain information about the alterations in $\mathrm{N}$ metabolism observed as a consequence of the overfeeding of lipid, we studied the capacity of hepatocytes to synthesize urea and glucose from several precursors. Table 4 shows that urea synthesis was greatly diminished in the hepatocytes isolated from overfed animals. This reduced capacity for urea production was manifested in the absence of exogenous precursors $(-25 \%)$, in the presence of $\mathrm{NH}_{3}$ plus ornithine $(-57 \%)$, by adding lactate to both compounds $(-36 \%)$, the combination that promoted the maximal urea production, and in the presence of alanine $(-32 \%)$, the main gluconeogenic amino acid.

The capacity of hepatocytes to synthesize glucose was evaluated from single additions of several precursors (alanine, lactate, pyruvate, glycerol and fructose), each one capable of taking part in diverse metabolic processes or being incorporated into the gluconeogenic pathway at different levels. As shown in Table 4, the hepatocytes isolated from the overfed 
Table 4. Urea and glucose synthesis from given precursors by isolated rat hepatocytes $\dagger$ (Values are means with their standard errors for six animals)

\begin{tabular}{|c|c|c|c|c|c|c|}
\hline \multirow{2}{*}{$\begin{array}{l}\text { Treatment group... } \\
\text { Additive }\end{array}$} & \multicolumn{2}{|c|}{ Control } & \multicolumn{2}{|c|}{ Overfed } & \multirow{2}{*}{$\begin{array}{c}\text { Percentage } \\
\text { change }\end{array}$} & \multirow{2}{*}{$\begin{array}{l}\text { Statistical } \\
\text { significance } \\
\text { of change }\end{array}$} \\
\hline & Mean & SEM & Mean & SEM & & \\
\hline \multicolumn{7}{|c|}{ Urea synthesis $(\mu \mathrm{mol} / \mathrm{min}$ per $\mathrm{g}$ wet $\mathrm{wt})$} \\
\hline None & 0.087 & 0.004 & $0 \cdot 065$ & 0.002 & -25 & $*$ \\
\hline $\mathrm{NH}_{4} \mathrm{Cl}+$ ornithine & 0.67 & 0.04 & 0.28 & $0 \cdot 02$ & -57 & * \\
\hline $\mathrm{NH}_{4} \mathrm{Cl}$ + ornithine + lactate & $2 \cdot 7$ & 0.2 & $1 \cdot 71$ & $0 \cdot 11$ & -36 & * \\
\hline Alanine & 0.28 & 0.03 & 0.192 & 0.012 & -32 & * \\
\hline \multicolumn{7}{|c|}{ Glucose synthesis $(\mu \mathrm{mol} / \mathrm{min}$ per $\mathrm{g}$ wet wt) } \\
\hline Alanine & 0.35 & $0 \cdot 02$ & $0 \cdot 230$ & $0 \cdot 016$ & -35 & * \\
\hline Lactate & 0.67 & 0.04 & 0.45 & 0.02 & -33 & $*$ \\
\hline Pyruvate & 0.68 & 0.04 & $0 \cdot 34$ & 0.04 & -50 & $*$ \\
\hline Glycerol & 0.56 & 0.04 & 1.48 & 0.05 & -14 & NS \\
\hline Fructose & $2 \cdot 21$ & 0.05 & 1.44 & $0 \cdot 14$ & -35 & $*$ \\
\hline
\end{tabular}

NS, not significant.

* $P<0.05$.

$\dagger$ For details of diets and procedures, see pp. $362-363$.

rats exhibited diminished production of glucose from all precursors, a more marked reduction from pyruvate $(-50 \%$ compared with controls) and negligible change from glycerol $(-14 \%$, statistically non-significant $)$.

\section{Glucose-metabolism enzymes}

Table 5 shows the activities of five enzymes involved in the control of gluconeogenesis, the main pathway for reutilization of deaminated $\mathrm{C}$ skeletons of amino acids (Hers \& Hue, 1983). Little change was observed in the activities of the three gluconeogenic enzymes measured in the liver of the animals: fructose-1,6-biphosphatase, phosphoenolpyruvate carboxykinase and pyruvate carboxylase (expressed per unit liver weight). However, when liver size was considered the activities were higher in the overfed group. On the other hand, the activities of glucose-6-phosphatase, the enzyme that allows glucose to be released by the liver, and that of pyruvate kinase, an important enzyme in the control of gluconeogenic-glycolytic flux (Pilkis et al. 1988), were diminished per unit liver weight: however, the differences were not significant when activities were expressed on a total liver basis. Since the maximal enzyme activities did not change so much in the overfed animals, the modifications in gluconeogenesis shown by the isolated hepatocytes could be attributable to an altered precursor availability (Kinney \& Elwyn, 1983) derived from an overall shift in hepatic energy metabolism toward lipogenesis induced by the overfeeding (Drewry et al. 1988).

\section{Urea cycle and amino acid catabolic enzymes}

To explain the changes observed in urea excretion and hepatic urea production from precursors we measured the activity of the five enzymes involved in urea synthesis. Table 6 shows these values. We found that the five enzyme activities were lower in the liver of the overfed animals than in the control ones when expressed as units/g liver. The most important activity reductions were shown by carbamoylphosphate synthetase I $(-36 \%)$ and argininosuccinate synthetase $(-57 \%)$, both of them important enzymes in the 
Table 5. Glucose-metabolism-related enzyme activities $\dagger$ in the liver of control and overfed rats

(Values are means with standard errors for six animals)

\begin{tabular}{|c|c|c|c|c|c|c|}
\hline \multirow[t]{2}{*}{ Treatment group... } & \multicolumn{2}{|c|}{ Control } & \multicolumn{2}{|c|}{ Overfed } & \multirow{2}{*}{$\begin{array}{l}\text { Percentage } \\
\text { change }\end{array}$} & \multirow{2}{*}{$\begin{array}{l}\text { Statistical } \\
\text { significance } \\
\text { of change }\end{array}$} \\
\hline & Mean & SEM & Mean & SEM & & \\
\hline \multicolumn{7}{|l|}{ Glucose-6-phosphatase } \\
\hline Activity $(\mathrm{U} / \mathrm{g})$ & 4.0 & $0 \cdot 3$ & $1 \cdot 38$ & $0 \cdot 14$ & -65 & * \\
\hline Total activity (U) & $32 \cdot 5$ & 1.8 & $12 \cdot 9$ & 1.0 & -60 & $*$ \\
\hline \multicolumn{7}{|c|}{$\begin{array}{l}\text { Fructose-1,6-biphosphatase } \\
(E C 3,1,3,11)\end{array}$} \\
\hline Activity $(\mathrm{U} / \mathrm{g})$ & 1.74 & 0.07 & 1.79 & 0.06 & +3 & NS \\
\hline Total activity (U) & $14 \cdot 2$ & 0.5 & $17 \cdot 0$ & $0 \cdot 8$ & +20 & $*$ \\
\hline \multicolumn{7}{|l|}{$\begin{array}{l}\text { Phosphoenolpyruvate } \\
\text { carboxykinase }\end{array}$} \\
\hline Activity $(\mathrm{U} / \mathrm{g})$ & $0 \cdot 36$ & 0.03 & 0.38 & $0 \cdot 03$ & +6 & NS \\
\hline Total activity (U) & $2 \cdot 9$ & 0.2 & $3 \cdot 6$ & $0 \cdot 3$ & +23 & NS \\
\hline \multicolumn{7}{|l|}{$\begin{array}{l}\text { Pyruvate carboxylase } \\
\text { (EC 6.4.1.1) }\end{array}$} \\
\hline Activity $(\mathrm{U} / \mathrm{g})$ & $78 \cdot 6$ & 1.9 & 86 & 4 & +9 & NS \\
\hline Total activity (U) & 639 & 8 & 815 & 8 & +28 & $*$ \\
\hline \multicolumn{7}{|l|}{$\begin{array}{l}\text { Pyruvate kinase } \\
(E C 2.7 .1 .40)\end{array}$} \\
\hline Activity $(\mathrm{U} / \mathrm{g})$ & $40 \cdot 5$ & 1.9 & $30 \cdot 0$ & $1 \cdot 5$ & -26 & $*$ \\
\hline Total activity (U) & 331 & 23 & 283 & 4 & -15 & NS \\
\hline
\end{tabular}

NS, not significant.

* $P<0.05$.

† Each enzyme activity was assayed in the appropriate cytosolic, mitochondrial or microsomal fraction of liver homogenate. One unit (U) of enzyme activity was defined as the amount of enzyme required to catalyse the formation of $1 \mu \mathrm{mol}$ product $/ \mathrm{min}$ at $25^{\circ}$, except for phosphoenolpyruvate carboxykinase $(E C 4.1 .1 .32)$ and glucose-6-phosphatase (EC 3 1.3.9) which were assayed at $37^{\circ}$. Values are expressed as $\mathrm{U} /$ total liver and $\mathrm{U} / \mathrm{g}$ liver to account for the different liver sizes.

$\ddagger$ For details of diets and procedures, see pp. 362-364.

regulation of the cycle (Schimke, 1962; Saheki et al. 1980; Meijer et al. 1990). The calculated total activities of these enzymes allowed a more accurate correlation with the in vivo data for urea excretion. Total activities of ornithine carbamoyltransferase, argininosuccinate lyase and arginase were unchanged, while total activities of carbamoylphosphate synthetase I and argininosuccinate synthetase were markedly diminished.

A similar concerted reduction in urea-cycle enzyme activities has been described in rats fed on low-protein diets (Schimke, 1962). It is also known that the time-course of change in the urea-cycle enzymes follows quite closely that of the change in the urinary $\mathrm{N}$ output after an increase or decrease in protein intake (Das \& Waterlow, 1974). Furthermore, similar changes have been reported in rats fed on an energy-rich cafeteria diet (Barber et al. 1985, 1987) in accordance with the $\mathrm{N}$-sparing effect of fat.

We place special emphasis on quantities of carbamoylphosphate synthetase I (Table 6). The availability of an immunoassay (ELISA) for this enzyme, the most important enzyme for the control of this metabolic pathway (Meijer et al. 1990), allowed us to correlate the changes in the enzyme activity with those in enzyme quantity (Table 6). In overfed rats this enzyme exhibited both an inhibition of activity and a reduction in quantity $(-22 \%$ per unit liver weight). Although the change in the activity was slightly higher than that in quantity, 
Table 6. Urea-synthesis enzymes, $\dagger$ carbamoylphosphate synthetase I (EC 6.3.4.16) aminotransferases and glutamate dehydrogenase (EC 1.4.1.3) in liver homogenates from control and overfed rats

(Values are means with their standard errors for six animals)

\begin{tabular}{|c|c|c|c|c|c|c|}
\hline \multirow[t]{2}{*}{ Treatment group ... } & \multicolumn{2}{|c|}{ Control } & \multicolumn{2}{|c|}{ Overfed } & \multirow{2}{*}{$\begin{array}{l}\text { Percentage } \\
\text { change }\end{array}$} & \multirow{2}{*}{$\begin{array}{c}\text { Statistical } \\
\text { significance } \\
\text { of change }\end{array}$} \\
\hline & Mean & SEM & Mean & SEM & & \\
\hline \multicolumn{7}{|l|}{$\begin{array}{l}\text { Carbamoylphosphate } \\
\text { synthetase I }\end{array}$} \\
\hline Activity (U/g) & $5 \cdot 4$ & $0 \cdot 3$ & $3 \cdot 44$ & $0 \cdot 16$ & -36 & * \\
\hline Total activity (U) & 44 & 3 & $32 \cdot 5$ & 0.8 & -26 & * \\
\hline Quantity (mg/g) & $8 \cdot 7$ & $0 \cdot 3$ & 6.8 & $0 \cdot 3$ & -22 & $*$ \\
\hline Total quantity (mg) & 71 & 3 & 65 & 4 & -8 & NS \\
\hline Activity :quantity ratio & 0.61 & 0.03 & 0.511 & 0.016 & -16 & NS \\
\hline \multicolumn{7}{|l|}{$\begin{array}{l}\text { Ornithine } \\
\text { carbamoyltransferase } \\
(E C 2.1 .3 .3)\end{array}$} \\
\hline Activity $(\mathrm{U} / \mathrm{g})$ & 227 & 11 & 179 & 10 & -21 & $*$ \\
\hline Total activity (U) & 1840 & 68 & 1710 & 128 & -7 & NS \\
\hline \multicolumn{7}{|l|}{$\begin{array}{l}\text { Argininosuccinate } \\
\text { synthetase } \\
(E C \text { 6.3.4.5) }\end{array}$} \\
\hline Activity $(\mathbf{U} / \mathrm{g})$ & $1 \cdot 17$ & 0.11 & 0.50 & 0.07 & -57 & * \\
\hline Total activity (U) & $9 \cdot 5$ & 0.8 & 4.7 & 0.7 & -50 & * \\
\hline \multicolumn{7}{|l|}{$\begin{array}{l}\text { Argininosuccinate lyase } \\
(E C 4.3 .2 .1)\end{array}$} \\
\hline Activity (U/g) & 3.68 & 0.17 & $2 \cdot 85$ & 0.03 & -23 & $*$ \\
\hline Total Áctivity (U) & $29 \cdot 9$ & $1 \cdot 3$ & $27 \cdot 3$ & $1 \cdot 4$ & -9 & NS \\
\hline \multicolumn{7}{|l|}{ Arginase $(E C 3.5 .3 .1)$} \\
\hline Activity $(\mathrm{U} / \mathrm{g})$ & 892 & 47 & 705 & 30 & -21 & $*$ \\
\hline Total activity (U) & 7238 & 279 & 6746 & 485 & -7 & NS \\
\hline \multicolumn{7}{|l|}{$\begin{array}{l}\text { Aspartate aminotransferase } \\
(E C 2,6,1.1)\end{array}$} \\
\hline Activity $(\mathrm{U} / \mathrm{g})$ & 53 & 2 & $49 \cdot 5$ & 1.8 & -6 & NS \\
\hline & 429 & 15 & 473 & 30 & +10 & NS \\
\hline \multicolumn{7}{|l|}{$\begin{array}{l}\text { Alanine aminotransferase } \\
(E C 2.6 .1 .2)\end{array}$} \\
\hline Activity $(\mathrm{U} / \mathrm{g})$ & 31 & 2 & $13 \cdot 1$ & 0.9 & -56 & $*$ \\
\hline & 250 & 15 & 124 & 6 & -50 & $*$ \\
\hline \multicolumn{7}{|l|}{ Glutamate dehydrogenase } \\
\hline Activity (U/g) & $9 \cdot 9$ & 0.5 & $5 \cdot 4$ & $0 \cdot 4$ & -45 & * \\
\hline Total activity (U) & 80 & 3 & 52 & 6 & -35 & * \\
\hline
\end{tabular}

NS, not significant.

* $P<0.05$.

$\dagger$ Enzyme activities were measured in liver homogenates. One unit (U) of enzyme activity was defined as the amount of enzyme required to catalyse the formation of $1 \mu \mathrm{mol}$ of product $/ \mathrm{min}$ at $37^{\circ}$ for urea-cycle enzymes or $25^{\circ}$ for others. Values are expressed as $\mathrm{U} /$ total liver and $\mathrm{U} / \mathrm{g}$ liver to account for the different liver sizes. Quantities of carbamoylphosphate synthetase I were measured by enzyme immunoassay.

$\ddagger$ For details of diets and procedures, see pp. 362-364.

the difference was not significant. From these results it is possible to disregard inhibitory effects and to conclude that the changes affected mainly the quantity of the enzyme.

Some authors have shown that adaptive changes in the urea-cycle enzyme activities are closely correlated with alterations in the actual amount of the enzymes (Schimke, 1964; Saheki et al. 1980; Cerdá et al. 1988). For long-term adaptations, changes in the amounts 
of the enzymes seem to be more significant in the regulation of this metabolic pathway than changes in intermediate or regulatory metabolites (Waterlow, 1986; Mejjer et al. 1990).

Table 6 also shows the activities of three important enzymes involved in the catabolism of amino acids and the availability of $\mathrm{NH}_{3}$ for synthesis of urea. Alanine aminotransferase and glutamate dehydrogenase activities showed a marked reduction in the liver of the overfed rats. However, aspartate aminotransferase activity remained unchanged. The activities of many enzymes of hepatic amino acid metabolism parallel the changes in the urea-cycle enzymes when protein intake is modified (Das \& Waterlow, 1974). In this sense, our results correlated well with the $\mathrm{N}$-sparing effect induced by the overfeeding with energy and fat.

Since the most important enzymes involved in the catabolism and elimination of the amino group of the amino acids showed reduced activities in the overfed rats, this could be due to a diminished amino acid degradation as a consequence of the availability of supplementary energy.

\section{CONCLUSIONS}

It is well known that the addition of a supplementary source of non-protein energy to an adequate diet improves $\mathrm{N}$ balance. However, the underlying biochemical mechanism whereby the energy excess affects $\mathrm{N}$ metabolism is still unclear. The large number of dietary manipulations used in this type of work, many of them at first sight inadequate, as discussed, has not aided understanding of these mechanisms.

To characterize the alterations in $\mathrm{N}$ metabolism in rats fed on high-energy lipid-rich diets at a constant intake of protein, we have developed a model of voluntary overfeeding based on liquid diets. In our study it was important to adjust precisely the concentration of each nutrient, to isolate only one nutritional factor (the amount of energy from lipid), to measure exactly the amount of each nutrient ingested daily by each animal, to obtain voluntary acceptance of the diet by the animals at least for an adequate period and to avoid stressful actions such as tube feeding. The described procedure has optimally met these requirements. Moreover, in our opinion it has some advantages over semi-synthetic powdered diets commonly used in this type of work.

Our study on $\mathbf{N}$ balance has been extended with information about the enzyme systems involved in the elimination of the amino group of amino acids (urea synthesis and related processes) and in the reutilization of the $\mathrm{C}$ skeletons (gluconeogenesis). The results reported in the present work seem to indicate reduced amino acid catabolism in overfed growing rats. If this assumption is true, the spared amino acids must be incorporated into tissue protein mass, possibly through changes in protein turnover (Reeds et al. 1980, 1981; Waterlow, 1986). As discussed, long-term modifications of urea-cycle and amino acidcatabolism enzymes could depend on the protein breakdown status (Reeds et al. 1980; Kinney \& Elwyn, 1983; Waterlow, 1986; Meijer et al. 1990). However, most of the work in this area of metabolism relates to short-term responses. It still remains a challenge to define the control mechanisms that are most important for long-term adaptations. Further studies are needed to progress in the knowledge of $\mathrm{N}$ economy.

Our findings may also have an application in human nutrition. Overfeeding with energy from lipid might be useful in the recovery of malnourished or injured people since it improves $\mathrm{N}$ metabolism through an important amino acid-sparing effect (for reviews, see Kinney \& Elwyn, 1983; Waterlow, 1986). However, the concomitant fat gain would be disadvantageous.

Finally, we want to point out that as the liquid overfeeding technique has proved to be highly versatile, accurate and easy, this method is probably applicable to a wide variety of 
nutritional studies on the metabolic responses to dietary manipulations in addition to those reported in the present paper.

The authors wish to express their appreciation to Ms Mariví Martínez for her enthusiastic interest and encouragement in the present study. They also thank Ms Rossana Estellés and Dr Joaquín Timoneda for their help in ELISA procedures. This study was supported by a grant from the Fondo de Investigaciones Sanitarias (FIS no. 88/1990), Ministerio de Sanidad y Consumo, Spain. Dr Ernesto Estornell was a fellow of the Plan de Formación de Personal Investigador, Ministerio de Educación y Ciencia, Spain.

\section{REFERENCES}

American Institute of Nutrition (1977). Report of the Ad Hoc Committee on standards for nutritional studies. Journal of Nutrition 107, 1340-1348.

Baginski, E. S., Foà, P. P. \& Zak, B. (1974). Glucose-6-phosphatase. In Methods of Enzymatic Analysis, vol. 2, 2nd ed. pp. 876-880 [H. U. Bergmeyer, editor]. New York: Academic Press.

Baltzell, J. K. \& Berdanier, C. D. (1985). Effect of the interaction of dietary carbohydrate and fat on the responses of rats to starvation-refeeding. Journal of Nutrition 115, 104-110.

Barber, T., Estornell, E., Estellés, R., Gómez, D. \& Cabo, J. (1987). Studies on the role of insulin in N metabolism changes in cafeteria-fed rats. Molecular and Cellular Endocrinology 50, 15-22.

Barber, T., Viña, J. R., Viña, J. \& Cabo, J. (1985). Decreased urea synthesis in cafeteria-diet-induced obesity in the rat. Biochemical Journal 230, 675-681.

Bergmeyer, H. U. \& Bernt, E. (1974a). D-glucose: Determination with glucose oxidase and peroxidase. In Methods of Enzymatic Analysis, vol. 3, 2nd ed. pp. 1205-1215 [H. U. Bergmeyer, editor]. New York: Academic Press.

Bergmeyer, H. U. \& Bernt, E. $(1974 b)$. Glutamate-oxaloacetate transaminase: UV assay, manual method. In Methods of Enzymatic Analysis, vol. 2, 2nd ed. pp. 727-733 [H. U. Bergmeyer, editor]. New York: Academic Press.

Bergmeyer, H. U. \& Bernt, E. (1974c). Glutamate-pyruvate transaminase: UV assay, manual method. In Methods of Enzymatic Analysis, vol. 2, 2nd ed. pp. 752-758 [H. U. Bergmeyer, editor]. New York: Academic Press.

Berry, M. N. \& Friend, D. S. (1969). High-yield preparation of isolated rat liver parenchymal cells. Journal of Cellular Biology 43, 506-520.

Cerdá, M., Jordá, A., Barber, T., Castell, J. V., Cabo, J. \& Timoneda, J. (1988). An enzyme immunoassay for the quantitation of rat liver carbamoyl-phosphate synthetase I. Analyfical Biochemistry 174, 687-692.

Das, T. K. \& Waterlow, J. C. (1974). The rate of adaptation of urea cycle enzymes, aminotransferases and glutamic dehydrogenase to changes in dietary protein intake. British Journal of Nutrition 32, 353-373.

Drewry, M. M., Harris, R. B. S. \& Martin, R. J. (1988). Developmental changes in response to overfeeding: effect on composition of gain, liver metabolism and adipocyte cellularity in rats. Journal of Nutrition 118, 194-198.

Frings, C. S., Fendley, T. W., Dunn, R. T. \& Queen, C. A. (1972). Improved determination of total serum lipids by the sulfo-phosphovanillin reaction. Clinical Chemistry 18, 673-674.

Garza, C., Scrimshaw, N. S. \& Young, V. R. (1976). Human protein requirements: the effect of variations in energy intake within the maintenance range. American Journal of Clinical Nutrition 29, 280-287.

Grisolia, S., Quijada, C. L. \& Fernandez, M. (1964). Glutamate dehydrogenase from yeast and from animal tissues. Biochimica et Biophysica Acta 81, 61-70.

Gutmann, I. \& Bernt, E. (1974). Pyruvate kinase. In Methods of Enzymatic Analysis. vol. 2, 2nd ed., pp. 778-783 [H. U. Bergmeyer, editor]. New York: Academic Press.

Hers, H. G. \& Hue, L. (1983). Gluconeogenesis and related aspects of glycolysis. Annual Review of Biochemistry $52,617-653$.

Inoue, G., Fujita, Y. \& Niiyama, Y. (1973). Studies on protein requirements of young men fed egg protein and rice protein with excess and maintenance energy intakes. Journal of Nutrition 103, 1673-1687.

Kinney, J. M. \& Elwyn, D. H. (1983). Protein metabolism and injury. Annual Review of Nutrition 3, 433-466,

Lieber, C. S. \& De Carli, L. M. (1982). The feeding of alcohol in liquid diets : two decades of applications and 1982 update. Alcoholism, Clinical and Experimental Research 6, 523-531.

Lieber, C. S. \& De Carli, L. M. (1986). The feeding of ethanol in liquid diets: 1986 update. Alcoholism, Clinical and Experimental Research 10, 550-553.

McCargar, L. J., Baracos, V. E. \& Clandinin, M. T. (1989a). Influence of dietary carbohydrate-to-fat ratio on whole body nitrogen retention and body composition in adult rats. Journal of Nutrition 119, 1240-1245.

McCargar, L. J., Clandinin, M. T., Belcastro, A. N. \& Walker, K. (1989 b). Dietary carbohydrate-to-fat ratio: influence on whole-body nitrogen retention, substrate utilization, and hormone response in healthy male subjects. American Journal of Clinical Nutrition 49, 1169-1178.

McClure, W. R., Lardy, H. A. \& Kneifel, H. P. (1971). Rat liver pyruvate carboxylase. I. Preparation, properties and cation specifity. Journal of Biological Chemistry 246, 3569-3578. 
Meijer, A. J., Lamers, W. H. \& Chamuleau, R. A. F. M. (1990). Nitrogen metabolism and ornithine cycle function. Physiological Reviews 70, 701-748.

Minari, O. \& Zilversmit, D. B. (1963). Use of KCN for stabilization of color in direct Nesslerization of Kjeldahl digest. Analytical Biochemistry 6, 320-327.

Moore, B. J. (1987). The cafeteria diet - an inappropriate tool for studies of thermogenesis. Journal of Nutrition 117, 227-231.

Munro, H. N. (1951). Carbohydrate and fat as factors in protein utilization and metabolism. Physiological Reviews 31, 449-488.

Munro, H. N. (1964). General aspects of the regulation of protein metabolism by diet and by hormones. In Mammalian Protein Metabolism, vol. 1, pp. 381-481 [H. N. Munro and J. B. Allison, editors]. New York: Academic Press.

Munro, H. N. (1978). Energy and protein intakes as determinants of nitrogen balance. Kidney International 14, $313-316$.

Nägele, U., Hägele, E. O., Ziegenhorn, J. \& Wahlefeld, A. W. (1983). Reagent for the enzymatic determination of serum total triglycerides with improved lipolytic efficiency. Clinical Chemistry 29, 1075-1080.

Naranayan, S. \& Appleton, H. D. (1980). Creatinine: a review. Clinical Chemistry 26, 1119-1126.

National Research Council (1978). Nutrient requirements of laboratory animals. Nutrient Requirements of Domestic Animals no. 10, 3rd ed. pp. 7-37. Washington, D.C.: National Academy of Sciences.

Nuzum, C. \& Snodgrass, P. (1976). Multiple assays of the five urea cycle enzymes in human liver homogenates. In The Urea Cycle, pp. 325-355 [S. Grisolía, R. Báguena and F. Mayor, editors]. New York: John Wiley \& Sons.

Opie, L. H. \& Newsholme, E. A. (1967). The activities of fructose-1,6-diphosphatase, phosphofructokinase and phosphoenolpyruvate carboxykinase in white and red muscle. Biochemical Journal 103, 391-399.

Pilkis, S. J., El-Maghrabi, M. R. \& Claus, T. H. (1988). Hormonal regulation of hepatic gluconeogenesis and glycolysis. Annual Review of Biochemistry 57, 755-783.

Ramirez, I. (1987). Feeding a liquid diet increases energy intake, weight gain and body fat in rats. Journal of Nutrition 117, 2127-2134.

Reeds, P. J., Cadenhead, A., Fuller, M. F., Lobley, G. E. \& McDonald, J. D. (1980). Protein turnover in growing pigs. Effects of age and food intake. British Journal of Nutrition 43, 445-455.

Reeds, P. J., Fuller, M. F., Cadenhead, A., Lobley, G. E. \& McDonald, J. D. (1981). Effects of changes in the intakes of protein and non-protein energy on whole-body protein turnover in growing pigs. British Journal of Nutrition 45, 539-546.

Reeves, P. G. (1989). AIN 76 diet: Should we change the formulation? Journal of Nutrition 119, $1081-1082$.

Rothwell, N. J. \& Stock, M. J. (1979). A role for brown adipose tissue in diet-induced thermogenesis. Nature 281, 31-35.

Rothwell, N. J. \& Stock, M. J. (1981). Regulation of energy balance. Annual Review of Nutrition 1, 235-256.

Saheki, T., Tsuda, M., Takada, S., Kusumi, K.\& Katsunuma, T. (1980). Role of argininosuccinate synthetase in the regulation of urea synthesis in the rat and argininosuccinate-associated metabolic disorder in man. Advances in Enzyme Regulation 18, 221-238.

Schimke, R. T. (1962). Adaptive characteristics of urea cycle enzymes in the rat. Journal of Biological Chemistry 237, $459-468$.

Schimke, R. T. (1964). The importance of both synthesis and degradation in the control of arginase levels in rat liver. Journal of Biological Chemistry 239, 3808-3817.

Shimazu, T. \& Ogasawara, S. (1975). Effects of hypothalamic stimulation on gluconeogenesis and glycolysis in rat liver. American Journal of Physiology 228, 1787-1793.

Siedel, J., Hägele, E. O., Ziegenhorn, J. \& Wahlefeld, A. W. (1983). Reagent for the enzymatic determination of serum total cholesterol with improved lipolytic efficiency. Clinical Chemistry 29, 1075-1080.

Warnick, G. R., Cheung, M. C. \& Albers, J. J. (1979). Comparison of current methods for high-density lipoprotein cholesterol quantitation. Clinical Chemistry 25, 596-604.

Waterlow, J. C. (1986). Metabolic adaptation to low intakes of energy and protein. Annual Review of Nutrition $6,495-526$. 